\title{
Imagining Utopia in Chabon's Telegraph Avenue
}

Myles Robert Oldershaw

Sudbury, Suffolk, England

B. A. (Hons) University of East Anglia, 2010

\begin{abstract}
A Thesis Presented to the Graduate Faculty
of the University of Virginia in Candidacy for the Degree of Master of Arts

Department of English
\end{abstract}

University of Virginia

May 2014 
In his essay "The Ends of Utopia," Krishan Kumar writes that authors "no longer turn to the utopian form or genre for imagining a better or more perfect future "(554). Contrasting the fallow period of recent decades to the late nineteenth and early twentieth centuries, when utopian novels by Edward Bellamy and H.G. Wells "seized the public imagination" (553), he argues that there is "quite simply nothing that commands the attention of the educated reading public in the way that those works once did" (554). In one sense, Kumar asserts, this is a problem of reception. Marketed to and consumed by increasingly narrow readerships, utopian novels no longer command the attention of the reading public. Consequently they languish, largely unnoticed, in isolated "cultural enclaves" (552) and are no longer able to spur or shape mass debate. While this development is undoubtedly damaging for the genre, Kumar discerns a more fundamental crisis in utopian fiction, one engendered by a challenge to the very precepts of utopianism.

Referring to the work of Zygmunt Bauman, Kumar highlights the centrality of the nationstate to previous utopian thought. Despite their critical stance towards contemporary modes of political organization, utopias "generally reflected the form of the modern nation-state, a territorially bounded entity which provided the necessary sovereign space for utopian imagining" (559). Alongside this territorial imitation of nation-states, they "also reflected the nation-state's search for a managed order, preferably one fixed and final and not subject to disruptive or disorderedly change" (559). The nation-state of modernity, then, provided the framework for flights of utopian fancy. Its appeal lay not only in its bounded spatial form, which enabled the demarcation of hypothetical utopian authority, but also its inner workings; its ceaseless ordering impulse attracted thinkers who sought stability and perseverance in their newly imagined world. Kumar argues that ideological and political developments over the past half-century, however, have critically undermined the nation-state in two respects, leaving utopian authors without a stable foundation on which to base their work. First, modernity has become increasingly distrusted. To many, it seems "to have overreached itself, to have shown an intolerable degree of self-certainty, 
rigidity, and dogmatism" (559). Its central notion of constant advancement now rings rather hollow, as do its grand narratives of reason and progress. Consequently, the appeal of the modern Western nation-state, wedded to claims of reason and organization, is no longer self-evident. Instead, it appears an unwieldy model of organization, prone to irrational and unethical spasms. Its pretensions towards "a social order based on a high degree of consensus" (556) and rhetorical claims to moral probity now appear less clear-cut, leading to widespread disillusionment and apathy.

Alongside this unease with the model of the nation-state, contemporary utopian authors have had to grapple with its growing inconsequentiality. Utopia "has become, within the logic of the globalized world, a contradiction in terms" (22). As multi-national corporations and the constant innovations of capital erode previous boundaries and fixity, the nation-state appears somewhat anachronistic. Not irrelevant, to be sure, but retrograde, superceded by the global networks and organizations, which, comparatively untethered, are able to outflank the bounded nation-state. In this environment, utopian thought can have no solid geographical base: "The 'u' of 'utopia,' bereaved by the 'topos,' is left homeless and floating, no more hoping to strike its roots, to 'reembed" (22).

Utopian thought is then doubly assailed. While the nation-state remains the model for utopian literature, it appears critically undermined by both its internal failings and its increasing global obsolescence, confronting utopian authors with "the difficulties and dangers of large-scale utopian projects - even if only in the imagination" (Kumar, 562). What, then, might the author with an urge to think in terms of utopia do, beyond suppressing such an urge entirely? In Utopia Limited, Marianne DeKoven convincingly argues for a reconsideration of the form's possibilities, insisting that it has become, in the era of postmodernism, "limited: muted, partial, local, diffuse, multiple, skeptical, complicit, displaced, and significantly refunctioned" (25). The challenge is to all utopias, which DeKoven contends have been fatally undermined by the postmodern critiques of sweeping universalism and the nation-state. Such a claim appears credible; given the challenge posed by 
postmodernism, how can one conceive of utopia as traditionally understood? The very notion has experienced a precipitous fall from grace.

My particular argument concerns the literary acknowledgement of this fall, and the future for utopia in the contemporary novel. As noted by Kumar, the one place the form now flourishes is science fiction, a genre which - despite various attempts to emphasize its significance ${ }^{1}-$ has failed to capture or interest a sizeable portion of the reading public, at least with regard to its political potential. How, then, have authors working outside the realm of sci-fi engaged with this decline? One appealing option for authors is surely, in supreme denial, to persist regardless. After all, as Peter Boxall argues, the nation-state's "residual structures for the organization of space and time" (188-9) are still the primary organizing structures of everyday life for all but the transnational global elite. Given this endurance of national form, the promise of a bounded, stable nation-state, on first reflection, may not seem so improbable after all. With the organizing structures of a new globalized world either out of everyday sight or as yet unbuilt, the nation-state is still the principal reference point of political thought for the vast majority of people. It would seem that a utopian author stubbornly determined to imagine an orthodox, nation-based utopia may quite easily persist in such a manner, despite the underlying weaknesses outlined above. What of other more conscientious utopian authors, however? How might they contain or express their utopian impulse given the weaknesses to its basic model? How might they attempt to balance visions of utopia with an awareness of the challenges that face the traditional bounded and ordered nation-state?

A recent novel that grapples with the possibility of utopia is Michael Chabon's Telegraph Avenue. Published in 2012, it marks a departure for the author, as it intently focuses on race, class, and politics to an extent that is absent in his previous work. On first reading, the novel appears to indicate the author's blind denial of utopia's demise. This impulse is readily apparent; hearkening back to earlier utopian fiction, it posits the existence of a just and egalitarian society on a national

1 Perhaps the most well-known being Fredric Jameson's Archaeologies of the Future: The Desire Called Utopia and Other Science Fictions (London: Verso, 2005) 
scale, which as I shall demonstrate, is depicted in the synecdoche of a much smaller community. Through this community, Chabon attempts to emphasize the budding potential for a unified American society, one in which the nation's myriad heterogenous citizens might equally and unequivocally share a common national identity. The willingness to envisage this specific utopia represents a break for Chabon, even though the subject of utopianism is broached in his previous novels. The Amazing Adventures of Kavalier and Clay, published in 2000, most clearly engages with the utopian promise of a separate, better, world, lavishing attention on the burgeoning subculture surrounding comic books in New York after the Second World War. The novel's titular Joe Kavalier reflects on this promise after losing his family in the war:

the usual charge leveled against comic books, that they offered merely an escape from reality, seemed to Joe actually to be a powerful argument on their behalf . . . The pain of his loss - though he would never have spoken of it in those terms - was always with him in those days, a cold smooth ball lodged in his chest, just behind his sternum. For that half hour spent in the dappled shade of the Douglas firs, reading Betty and Veronica, the icy ball had melted away without him even noticing. That was the magic - not the apparent magic of a silk-hatted card-palmer, or the bold, brute trickery of the escape artist, but the genuine magic of art. (575-6) The passage illustrates the conscious attempt to believe in utopianism, to believe in the unlikely escape to a better world, and it typifies the faith in utopia that runs through Kavalier and Clay. It is, however, the product of a nostalgic utopianism, one only able to imagine utopia in a past that bears little resemblance, politically, culturally, or economically, to the present. Although the novel then appears to endorse utopian flights of fancy, it is only able to do so with regard to the past, implicitly calling into the question the practicality of any contemporary utopianism. Chabon's powerful emotional connection to the comic books of the post-war era simultaneously fosters and superannuates his utopian longing, offering it a conduit through which to develop but confining it to 
a period and form specific to an unattainable past. While Telegraph Avenue is similarly suffused with nostalgic desire, its idealized community, by contrast, sits squarely in the present-day, and is central to much of the novel. This seemingly attests to Chabon's belief in the current viability of utopianism.

Telegraph Avenue should not be understood, however, as stubbornly or blindly advocating a new American utopia. While we may discern a clear utopian impulse behind Chabon's narrative, this is accompanied by a less buoyant or hopeful air. The novel evinces a disillusionment or disbelief in the necessity or distinction of the nation-state, as well as an awareness of alternative local and global forms of community. For Chabon, disillusionment has an ethical basis: he repeatedly acknowledges how America's transformative potential and foundational promise has been undermined, and depicts the resultant inequality and prejudice as fundamentally unfair. These passages disturb the concept of an equal and shared national identity, and as such, present a stark challenge to the novel's utopian strain. This fundamental antagonism, built into the structure of the work, underpins Telegraph Avenue.

For much of the novel, Chabon appears content to simply juxtapose these antagonistic elements, as if having reached the authorial "impasse" (560) that Kumar describes. The first, utopian, impulse is apparent in the novel's central plot, which focuses on Brokeland Records, a small, independent record store in the Bay Area. The store's owners, as well as its customers, pay scant interest to differences of race. While their racial and cultural difference is acknowledged, it is secondary to notions of unity and parity. The characters synecdochally evoke an America beyond inequality and prejudice. Oppression based on "sex, gender, race, and all that piddly shit" (Chabon, 120 ) is absent in the haven of the record store. In this utopian strain, Chabon has a formidable literary forebear, one that is referred to at multiple points in the novel: Melville's Pequod similarly serves as a site for the imagining of an alternative, heterogenous, United States. Unlike this floating utopia, however, Chabon's store is squarely embedded in everyday American life. Sitting on the 
border between Berkeley and Oakland, Brokeland is one of the few remaining businesses in an economically struggling area. Outside of the store, the novel depicts the lives of numerous interconnected secondary characters, and it is through these characters that we may discern Chabon's second, skeptical impulse. They experience and comment on the ways in which race stratifies and divides Americans, and acknowledge the enduring effects of historic forms of oppression. Much of Telegraph Avenue appears a sort of balancing act, an attempt to admit and express the fissures that scar American society while also holding out hope for its utopian redemption. In part, then, my essay shall attempt to delineate this structure behind the novel; doing so, I believe, not only illuminates the impasse in Chabon's thought, but helps exemplify the decline or frustration of utopia that Kumar outlines. This impasse, furthermore, best explains the turn to nostalgia in the novel, with the cultural products of the 60 s and 70 s the only channel through which Chabon's utopian longing may advance unchecked. Unable to reconcile this longing with its valid critique, he retreats to the idealized past. In the process of describing the novel's structuring 'deadlock,' therefore, I also shall trace the novel's persistent nostalgia. By clarifying its cause and mapping its effects, I hope to account for this enduring feature of Chabon's work.

Conceiving of the novel in such in a manner, however, does not entirely account for its content. While much of Telegraph Avenue comprises the unresolved clash between utopianism and skepticism, as well as its nostalgic corollary, its conclusion decisively terminates this dynamic. Chabon eventually deems the novel's two structuring impulses mutually exclusive, and rejects Brokeland's utopian promise of a shared and equal national identity. The business is ultimately closed, with the chance of it ever returning dismissed as airy idealism. The conclusion is undoubtedly a renunciation of the store's symbolism, and appears a reluctant acquiescence to DeKoven's claim, with the national utopia of the store eschewed in favour of more incremental change. Yet, this interpretation, in which Chabon belatedly corroborates Kumar's narrative of decline, overlooks a more complex truth to the ending. While the novel rejects a specifically 
national utopia, it presents alternative sites where commonality may be recognized and equality tentatively realized. Chabon is aware of global and local alternatives to the organizing structures of the nation-state, and begins to explore the utopian potential of these alternative spaces. It would be mistaken, therefore, to understand this development as the wholesale rejection of utopia. Rather, what Chabon rejects is the specific form of utopia that inheres in the store, one dependent on the organizational structures of modernity outlined by Kumar and Bauman. Pointing to the unifying power of global technology, the conclusion rather sustains his desire by hinting at new forms of utopian community. This original direction for utopian thought, although by no means explored in great detail, represents an attempt to envisage spaces of promise that are free from the calcified form of the nation-state, and that surpass the limiting constraints imposed by postmodern critique. It is my contention, therefore, that Telegraph Avenue offers a model for conceiving of large-scale utopia that is neither retrograde nor insensible to political change. Indeed, it is acutely responsive to, and only feasible in, the contemporary world and its political climate. Intervening in the prevailing skepticism surrounding utopianism, Chabon challenges the claim that contemporary utopias must necessarily be limited, and begins a possible route to their recuperation and realization.

Before I begin to delineate the antagonistic impulses at the center of Telegraph Avenue, it would perhaps be helpful to explain my rationale for writing on Michael Chabon. It is true that Chabon is generally perceived as a 'middlebrow' author, and has not been the subject of sustained critical attention. Despite this fact, I would argue that an essay such as mine is justified for a number of reasons. While he is not as experienced or esteemed as writers such as Don DeLillo or Toni Morrison, Chabon's influence on contemporary American fiction is not insignificant; having won the Pulitzer Prize for The Amazing Adventures of Kavalier and Clay in 2001 and been inducted into The American Academy of Arts and Letters in 2007, his place in the literary establishment is secure. Although he is not, of course, wholly representative of the myriad novelists writing today some of whom would share the skepticism surrounding utopia summarized and articulated by 
DeKoven - he is one of the most popular. If one is to accurately assess the standing of utopia in fiction today, then one must turn to its manifestation in literature such as Chabon's which, in capturing the attention of a wide reading public, both shapes and responds to the perception of the genre across a variety of social and cultural contexts. I do not mean to evaluate, positively or otherwise, the 'literariness' of Chabon's writing, but to consider its relationship to the narrative of popular utopian fiction that Kumar describes in his article. Rather than deterring any sort of study, therefore, it is Chabon's perceived 'middlebrow' (a problematic term in itself) status that necessitates a thorough consideration of his writing. As I shall go on to illustrate, Telegraph Avenue is not the product of an idiosyncratic utopian longing, out of step with its time, but rather a novel that reflects on and responds to a parallel contemporary discourse of change, a discourse newly resurgent in American society and one explicitly referred to in the narrative. Although unable to fully assent to its assumptions, Chabon endeavours to channel its prevailing impetus into the tentative model of utopia that he proposes. Through this reconfigured model, therefore, he attempts to recuperate utopianism not only as an authentic and viable literary genre, but as a popular one as well.

Turning to Brokeland Records, we may see how Chabon asserts similarity rather than difference in the community of the store. His central characters, Nat Jaffe and Archy Stallings, own the business and share a love of 1970s soul. What unites the two men - beyond the fact they would both "wage wars, found empires, lose their dignity and their fortunes for the sake of vinyl" (493) is their shared belief in their store's status as a space in which differences of identity barely matter. Archy compares Brokeland to an oasis

on the old Silk Road ... It's all tribes and deserts ... all around you, the tribes just want to keep up their warring, and killing, and keeping track of what makes them better than everyone else ... every so often, every few hundred miles, maybe, you got these oases, right, these caravanseries, where they all get together and chill, hang out, listen to good music, swap wild tales of exaggeration ... The Brokeland Creole 
dream. (504)

While Archy romanticizes the store, he accurately recognizes the diverse nature of his 'oasis.' The store owners themselves - Nat white and Archy black - exhibit this diversity. Their patrons - Mr. Mirchandani, the Indian owner of neighbourhood gas stations, Mike Oberstein, a prominent local lawyer and "sweet-natured white guy from Indiana" (41), and Chan Flowers, Oakland city councilman and ex-Black Panther - ensure that, at least with regards to race, the record store approximates the 'Brokeland Creole' ideal of its owners. The differences between its inhabitants are acknowledged, but secondary to its ethos of friendship and cooperation.

We may see, then, that the composition alone of Brokeland indicates the novel's utopian urge to illustrate an America beyond division. This urge is underlined by the central drama concerning the business, which is the imminent opening of a corporate record store in the neighbourhood. This new store, named Dogpile, is "five times as big [as Brokeland] . . . and tenfold deep" (308). The resultant solidarity that this threat engenders, with a protest meeting drawing a concerned crowd "from a disparate set of social contexts" (270), stresses the store's centrality to the novel's hopeful strain. Furthermore, the corporate store specializes in African-American music, and this explicit focus on a single racial identity throws Archy and Nat's 'Brokeland Creole' into heightened relief. When Archy is offered a job by the owner of the new store, who links the opportunity to historic racial oppression, he voices his suspicion of the race-conscious rhetoric of his interlocutor: "Going to tell me now's my chance to make history ... strike a blow for the race by bailing out on my white oppressor" (315). In eschewing the focus on difference, Archy's sarcastic response echoes his earlier sentiments on Brokeland's symbolism. He underlines this position during a later eulogy for a longtime customer of his store. Reflecting on the life of local character and semi-famous musician Cochise Jones, who termed his music 'Brokeland Creole,' Archy comments:

Creole, that's, to me, it sums it up. That means you stop drawing those lines ... Cochise Jones, his mother was mostly, uh, Choctaw, I think it was. Me, my father's 
half Mexican, which is already half something else. Brokeland Creole. Around here used to be Mexico, before that, Spain, before that Ohlone. And then white people, Chinese, Japanese, black folks bringing that bayou, that Seminole, that Houston vibe. Filipinos. Toss 'em on the grill, go 'head. Brokeland Creole. And some more Mexicans, Guatemalans. Thai, Vietnamese. Hmong. Uh, Persian. (503) Although unsophisticated, Archy's paean to the community's diversity attempts to underscore the connectedness of its inhabitants. It situates each resident ethnicity equally "on the grill" of local life, establishing a shared identity among them all. The directive to "stop drawing those lines," out of character for the usually unassertive Archy, seems an intrusion of Chabon's own voice into the narrative. Giving voice to the author's utopian longing, it exhorts the members of the community to recognize their commonality.

Archy then exhorts a form of egalitarian social organization that is assuredly utopian, and the solidarity demonstrated by Brokeland's diverse array of supporters cements the store's status as a speculative utopian community. Critically, this symbolism extends beyond the local environs of the East Bay, as the store does not merely represent the possibility inherent in the cities of Berkeley and Oakland - whose shared border it straddles - but rather that of the nation. This sweeping representative scope, revealed in the novel's intertextual and political allusions, distinguishes Brokeland from the 'limited' utopianism that DeKoven argues is characteristic of postmodernism, indicating by contrast the belief in a viable utopia of the nation-state. In displaying such ambition, Chabon draws on both a historical literary tradition and a popular contemporary discourse.

One aspect of Telegraph Avenue which evinces this ambition is its multiple intertextual references to Moby-Dick; the novel's epigraph is "Call Me Ishmael," and Mike Oberstein, regular visitor to the Brokeland stacks, is nicknamed 'Moby.' As with Melville's Pequod, the store comprises a motley assortment of individuals, whom Chabon likewise unites in the face of a common foe. The giant zeppelin of Dogpile CEO Gibson Goode, flown over Oakland in a nod 
towards the business' impending arrival, represents the looming commercial threat that plays on the mind of Archy and Nat. Hanging ominously over the city, it troubles Nat especially, for whom it represents, "as with Ahab's fish ... all the ways in which the world was broken" (559). The combined effect of these references is to draw attention to how Chabon, like Melville, imagines an alternative, heterogeneous United States, one symbolized in the fragile unity of a diverse group. Such an undertaking is not exclusive to Melville, of course; Lawrence Buell argues that the narrative depiction of this sort of group - what he somewhat inelegantly calls the "heterogeneous symbolic assemblage of individuals" - has long been employed as one of the "recipes" by which an author can concoct the Great American Novel. ${ }^{2}$ Often "positioned in a confined space in the service of a common task," these individuals constitute "an image of democratic promise" (138). While Buell's essay perhaps overdetermines the Great American Novel, it helpfully highlights the tradition of literary nation-building that Chabon draws on and prolongs through Brokeland's 'symbolic assemblage,' and underscores the scope of his utopian enterprise.

In my introduction, I argued that Chabon explicitly connects this enterprise to a popular contemporary discourse, thereby substantiating its claim to widespread relevance. Although undoubtedly apt at analogously displaying the range of Chabon's ambition, the allusions to MobyDick do not establish the contemporaneity of Brokeland's utopianism. Rather, they tie it to a tradition. By contrast, the cameo appearance of Barack Obama in the middle of the novel - or more specifically, the commentary that Chabon offers on his significance - serves to emphasize the similarities between Brokeland and Obama's rhetorical invocation of America. In suggesting the proximity between the wildly popular national imaginary of Obama's speeches and the utopian national imaginary propounded by Brokeland, Chabon traces an enduring hunger for utopian thought in American society, in the process establishing Telegraph Avenue as both a reflection of and response to this hunger. The actual space afforded to Obama in the novel is minimal; the then-

2 Alongside Moby-Dick, Buell recognizes this device in Dos Passos' U.S.A. Trilogy, Mailer's The Naked and the Dead, and Pynchon's Gravity's Rainbow. 
state senator, yet to have acceded to the position of President, makes small talk with Archy's wife Gwen before stepping onto the stage at a fundraiser for the upcoming 2004 presidential election. His remarks veer close to platitudinous and do little to propel the plot. The words he offers to the assembled crowd, presumably of more import, are not included in Chabon's narrative. We are told, however, as the only scrap of meaningful background about the otherwise unremarkable state senator, that he "had given a wonderful speech last month at the Democratic Convention in Boston" (215). Such explicit commendation is not surprising, perhaps, given Chabon's description of Obama as someone who "comes off at once brilliant and sensible, vibrant and measured, engaged and engaging, talented, forthright, quick-witted, passionate, thoughtful and . . reasonably humble" ("Obama vs. The Phobocracy"). I would argue, however, that if we consider the content of this speech, it becomes apparent that its mention, and the mention of Obama in general, represents more than mere partisan promotion.

In the speech of July 2004, Obama emphasizes similarity, deriding "those who are preparing to divide" Americans, "the spin masters and negative ad peddlers who embrace the politics of anything goes" (Transcript). In an echo of Archy's command to "stop drawing those lines," Obama insists "There's not a liberal America and a conservative America; there's the United States of America. There's not a black America and white America and Latino America and Asian America; there's the United States of America" (Transcript). Emphasizing an inclusionary and sweeping view of American identity, he argues that while citizens may "pursue [their] individual dreams," they "still come together as an American family" (Transcript), evoking a shared national identity which eclipses all others. This identity can trump division, can allow cultural richness while uniting and equalizing a heterogenous group. As Obama's introduction to the national stage, the speech establishes the themes of hope and change, hope in change, over which the 2008 election was later fought. Obama calls hope "the bedrock" of America, and tells the audience to harbour "a belief in things not seen, a belief that there are better days ahead" (Transcript). He insists that "out of this 
long political darkness a brighter day will come" (Transcript). It is this anticipatory quality, in the service of a transformed vision of the country, that renders the speech utopian. Despite the acknowledgement of various challenges - poverty, unemployment, illiteracy - to its rhetorical promise of justice and equality, it presents an unquestionably clear prospect for America. This rhetoric does not originate with Obama, who draws on a long oratorical tradition - seen in the speeches of Winthrop, King, and Reagan, among others - of heralding a resplendent American future. Yet, in harnessing the tradition to such effect in 2004 and 2007-8, Obama proved its lasting communicative appeal to a majority of the American public.

Given, then, the utopian character of the convention speech, its inclusion in the context of Brokeland Records is pointed. Although formally distinct from Chabon's literary utopianism, the content of Obama's speech bears conspicuous resemblance to the narrative surrounding the symbolic record store. Both men present a scene of equality and justice, with parity amongst its occupants. In both cases - explicitly for Obama, metaphorically so for Chabon - the utopian scene is not 'limited' or 'skeptical,' as DeKoven claims it must be, but rather sweeping and hopeful. The speech, therefore, functions as a demonstrable analogue for Chabon's utopian project, serving to ground the latter in a popular contemporary discourse of which the pre-election Obama was the most prominent mouthpiece. In this way, Brokeland's contemporaneity, its appositeness to the present day, is assured.

Yet if the inclusion of Obama highlights and substantiates Chabon's utopianism, it simultaneously deflates reader expectations, acting as a caution against this line of thought. Written eight years after Obama's convention speech, the novel is able to remind contemporary readers of the air of anticipation that surrounded the pre-presidential Obama. With the benefit of hindsight, the widespread hope that his presidency could usher in a new era of bipartisan comity, could help to realize the America of his speech, appears tragically over-optimistic. The book's encouragement of this retrospective evaluation, this comparison between Obama-the-candidate and Obama-the- 
president, is not the barbed result of authorial disdain for the president and his personality; speaking in 2012, Chabon said that "considering what [Obama]'s had to deal with . . . he's done better than anybody else who could have become president could've done" (O'Hehir, web). Rather, it is a comment on the utopian thinking that accompanied the candidate, imbuing his putative presidency with a transformative potential that was far beyond his means. In this context, even as the mention of Obama demonstrates the contemporary prominence of sweeping utopian rhetoric, it encourages a recognition of its necessary artificiality; in retrospect, the stirring image of America in the convention speech appears less an act of confident, declarative, description - 'There is not a liberal America and a conservative America; there is the United States of America' - than one of hopeful invocation. In the context of Telegraph Avenue as a whole, Brokeland Records acquires a similarly forced air. Chabon's secondary plots sketch the lives of numerous other neighbourhood residents in passages that run parallel to, and occasionally in concert with, Archy and Nat's struggle. Portraying Archy and Nat's wives Gwen and Aviva, Nat's gay son Julie, and both Archy's long-lost son Titus and absent father Luther, these passages communicate some of the radical divisions in their society. As a function of Chabon's disillusionment with the American state, they call attention to the historical and institutional quality of these divisions, and challenge the utopianism of Brokeland. Part of the starkly realist world of these characters, the store appears somewhat fanciful, a result of authorial fiat rather than credible imagination.

One such passage focuses on Archy's black wife Gwen, who runs a home midwifery business with Nat's white wife Aviva. Her narrative hints at the incommensurability of everyday life and Archy's unifying, equalizing, 'Brokeland Creole.' An argument with a nurse prompts her to consider her relation to authority, which is portrayed in starkly racial terms: "To the extent that [she] had been hassled in her life by representatives of the white establishment, she had been trained to get the better of the situation without compromising herself' (80). After Aviva has to step in as peacemaker, Gwen thinks about pointing out "that if you were white, eating shit was a choice you 
could make if you wanted [but] for a black woman, the only valid choice was not to" (82). In acknowledging racial privilege, the passage is one example of the urge in Telegraph Avenue to recognize the unequal structures that lie behind everyday life. It alludes to the broader fractured landscape of American race and its institutional preservation, a fact that Gwen, who has clashes with numerous adversaries, returns to at various points in the novel. The passage is one of many which speaks to an urge to recognize the disjunction between the tenor of Brokeland and its wider surroundings. Although the utopianism of the novel's central plot proceeds unchecked, it is increasingly called into question from the narrative perspective of Chabon's secondary characters.

Another expression of Chabon's disillusionment comes later in the novel, when Gwen goes into labour. Pregnant at the start of Telegraph Avenue, Gwen enters her local hospital having temporarily split up with Archy. While thinking about her unborn son, she once again highlights the fissures in the Brokeland image of America: "she was about to bring another abandoned son into the world, the son of an abandoned son. The heir to a history of disappointment and betrayal, violence and loss. Centuries of loss, empires of disappointment" (606). Chabon here positions present-day inequity at the end point of centuries of history, contextualizing and intensifying the sense of radical injustice that Gwen contemplates after her argument with the nurse. Archy's father Luther also turns to history in this way, linking the deprivation of modern-day Oakland to historical forms of neglect and exploitation. In an attempt to educate Archy and Nat's sons, he articulates a "Secret History" which, with a "sense of sweep across time and territory," details Oakland's rise and fall. The history focuses on the struggle of black Americans to settle in the area when "the Klan march[ed] down Broadway in broad daylight as white Oakland lined the streets cheering," and reflects on the lost promise of work in the city shipyards, where "strikes and black labor unions" (426) previously engendered a sense of unity. The challenges to utopia are then not only shown to exist in the present, but to have roots and causes stretching hundreds of years into the past. The ingrained nature of these roots and causes only further complicates the viability of the Brokeland project. 
The racial and economic divisions of the Bay Area are also depicted through the contrast that the novel draws between East Oakland, where "depopulated blocks . . . seemed to have been flattened by some economic meteor impact" (407) and more prosperous Berkeley, where Gwen and Aviva cater to well-off yuppies. The narrative repeatedly underscores the contrast between the lives of residents in each area. Lawyer Garth Frankenthaler, the husband of one of Gwen and Aviva's clients, exemplifies this contrast. He becomes excessively concerned during the birth of his child because, the reader is told, he "had absorbed from his poor black and Latino clients powerful notions of the sovereignty of bad luck and death. ... [Having] suffered no ill fortune throughout the length of a tranquil, comfortable and fulfilling life ... [he] felt that he deserved - the swift equalizing backhand of universal fortune" (74). The quote illustrates not only the gulf between Frankenthaler and his clients, but also his inability to comprehend its nature. While aware of the divide between his comfort and his clients' immiseration, he attributes its existence to a quirk of fortune, failing to consider the intractable drivers of disparity that preoccupy Gwen and Luther. Pegged by Gwen as "the gently feckless type of Berkeley white guy" (74), Frankenthaler stands as a representative for the caricatured white middle- and upper-classes of the area, the "fetishists and cultists, prone to schism and mania, [who were] liable to invest all their hope of heaven in the taste of an egg laid in the backyard by a heritage-breed chicken" (388). Sympathetic to the plight of others around them, they nevertheless appear unable to effect any substantial change. Garth is only one of numerous Berkeley and Oakland residents skewered in this manner; although Chabon is not scathing of these characters - perhaps, given that he lives in Oakland, counting himself among their number - the narrative expresses exasperation at their passivity and ineffectualness, once more hinting at the unlikelihood of utopian change.

These various passages demonstrate the disjunction between Chabon's central and secondary plots, which evoke antagonistic worlds. Archy and Nat's is one that has flown the nets of national history and prejudice, yet it exists alongside the world of Gwen, Luther, and other secondary 
characters, who are fully enmeshed in, and (bar Garth Frankenthaler) fully cognizant of, America's unequal forms and norms. Just as the symbolism of the Brokeland narrative extends beyond the confines of the Bay Area, the inequity of these passages is shown to surpass the individual lives or locales of Chabon's characters. Their inclusion reflects an awareness of the various ways in which the utopian ideals of the Brokeland narrative are, and have been, flouted in America as a whole. As such, they exemplify the grievances against the nation-state which Kumar describes; the product of a modernity that has 'overreached itself,' they exist alongside an idealistic backdrop of American progress and virtue. In focusing on how centuries of history and societal norms support present-day forms of oppression, forms which bleed into and affect the lives of the Brokeland owners, the novel not only questions whether the sort of shared nationwide identity spoken of by Obama can viably trump deep-set division, but whether the national should be the basis for a shared identity at all.

For most of Telegraph Avenue, Chabon juggles this critique with its object of criticism, his narrative oscillating between characters and settings. As noted, Brokeland and its accompanying symbolism is repudiated in the novel's final pages, but only after the extended progression and development of its plot. If the aforementioned secondary plots betray a strongly-felt sense of obligation, of necessary recognition, to American utopianism's myriad challenges, then the persistence of the Brokeland plot evinces an equally dogged attachment to its abiding possibility. It is in this context, with neither aspect being downplayed or curtailed, that we must understand the nostalgia that suffuses the novel; the past provides an outlet for Chabon's utopian longing, which is unable to find purchase in the complex and 'messy' present. Linda Hutcheon describes this dynamic in her essay "Irony, Nostalgia, and Postmodernism":

nostalgia is less about the past than the present. It operates through what Mikhail Bakhtin called an 'historical inversion': the ideal that is not being lived now is projected into the past ... The simple, pure, ordered, easy, beautiful, or harmonious past is constructed (and then experienced emotionally) in conjunction with the present - which, in turn, is constructed as 
complicated, contaminated, anarchic, difficult, ugly, and confrontational. ("Nostalgia, Irony, and the Postmodern")

Each construction sustains and is sustained by the other for Hutcheon, in a relationship that renders the past "prelapsarian," even "utopian" ("Nostalgia"). Archy and Nat are the prime conduits of Chabon's utopian nostalgia, expressed most overtly toward the vinyl records that inhabit Brokeland, but also toward the movies, muscle cars and delicacies of the past. Archy enters a local bakery to buy a "Dream of Cream," the favourite cake of his childhood, and is instantly filled "with a sense of loss so powerful that it almost knocked him down" (147). Taking in the wares racked in front of him, he instinctively compares past and present, reflecting that "the cakes and cookies at Neldam's were not first-rate, but they had an old-fashioned sincerity, a humble brand of fabulousness, that touched [him] in this time when everything good in life was either synthesized in transgenic cyborg vats or shade-grown in small batches by a Buddhist collective of blind ex-Carmelite Wiccans" (148). The passage, replete with a Proustian undertone, echoes Hutcheon's interpretation of nostalgia, in which "the invocation of a partial, idealized history merges with a dissatisfaction with the present" ("Nostalgia").

Archy's connoisseurship is not only limited to cakes; he harbours an interest, bordering on obsession, with the jazz and funk music of the $60 \mathrm{~s}$ and 70 s, and the records that fill the shelves at Brokeland induce a reverence in him and Nat evocative of Chabon's own self-professed fandom (Marchese, web). The meticulous inventories of authentic records that dot the narrative as part of Archy's thought process - “Electric Byrd (Blue Note, 1970). Johnny Hammond. Melvin Sparks's first two solo albums. Charles Kynard, Wa-Tu-Wa-Zui (Prestige, 1971)" (4) - testify to the ardent nostalgia induced by the listed items in both character and author. Once more, the past and its vestigial artefacts are imbued with a utopian purity that belies dismay at the present; that Brokeland specializes in these artefacts leads Archy to believe himself "a holdout, a sole survivor" in the contemporary world, "the last coconut hanging on the last palm tree on the last little atoll in the path 
of the great wave of late-modern capitalism, waiting to be hammered flat" (146). It is perhaps little surprise that Chabon leaves Archy the character most stricken by nostalgia - as the frequent conduit of Chabon's thoughts, he is the mouthpiece for the utopian impulse behind Brokeland Records, and most cognizant of its impracticability. Perceiving the disjunction between the store and its wider social context, he finds solace in the idealized past, and in turn apprehends the present as irreparably fallen. The glut of nostalgia in Telegraph Avenue bespeaks a similar process on the part of the author, who recedes into the past from a seemingly irresolvable contemporary impasse.

Nostalgia then functions as a relief from the 'deadlock' between Chabon's skepticism and utopianism, with the past reinterpreted to accommodate the latter. However, while the narrative openly partakes in wistful reverie, it also contains an acknowledgement of nostalgia's delusive effects. One passage is set at a regional memorabilia show, and is told from the perspective of 'Mr. Nostalgia,' a trader whose table is "replete as a Vegas buffet with choice offerings in the nonsports line that he had made his speciality and metier" (19). In one respect, the character allows Chabon to make self-referential and playful jabs at the kind of obsessive completism that characterizes amateur enthusiasts - one of Mr. Nostalgia's prize goods is “a complete set of the 1971 Bobby Sherman Getting Together cards, including the very tough number 54" (19). More significant, though, are the trader's reflections on his merchandise and customers. At first, nostalgia only comes in for implicit, and rather mild, attack: we are told that Mr. Nostalgia is under "no illusion" regarding his items' merely subjective worth. Their value, rather than intrinsic, is "indexed only to the sense of personal completeness, perfection of the soul, that would flood" customers when they "filled the last gap on [their] checklist" (26). The paragraph not only highlights that the various idées fixes of nostalgia are objectively worthless; it also pinpoints the irrationality nostalgia can occasion in one's thoughts and actions. After all, Mr. Nostalgia can only sell "a 1936 Wolverine gum card, 'The Fight with the Shark,' for \$550 to a dentist from Danville" (29) because of his client's belief that the purchase will, however temporarily, 'complete' his 'soul'. As an intrusion of authorial 
commentary, however, this paragraph is rather accommodating of nostalgia, indulging it as relatively harmless folly. The next reflection, by contrast, is more condemnatory of nostalgia, and evinces Chabon's self-conscious awareness of the pitfalls of any such extended indulgence. After lying about the value of a card to Archy's father, Mr. Nostalgia is overcome by the pachyderm weight of a grief that encompassed him and Stallings and every man plying his lonely way in this hall through the molder and dust of the bins ... The past was irretrievable, the league of lonely men a fiction, the pursuit of the past a doomed attempt to run a hustle on mortality. (28)

As Chabon complicates the Brokeland narrative through Gwen, Luther, and other secondary characters, he then complicates the subsequent turn to nostalgia through the character of Mr. Nostalgia. It allows him to question his own retreat to the past, with the obsessiveness of the nostalgic collector reduced to nothing more than a futile absconsion from the present. The characterization is rather too self-reproachful on Chabon's part, but it illustrates his fundamental dissatisfaction with the supposed salve of nostalgia. Although fertile fictional ground, it offers no resolution to the narrative impasse in Telegraph Avenue. It is only in the novel's final pages, however, that Chabon appears to break from this impasse - and by extension from extended nostalgia - when his repudiation of Brokeland Records becomes apparent.

After repelling the invasion of Dogpile Records, Archy and Nat are nonetheless forced to cease trading, the financial pressures on their permanently-ailing business having become too much to contain. They make the decision to go their separate ways: Nat to sell their leftover stock online, and Archy to become a real estate agent. In their final conversation, Nat concretizes the impression, hinted at by the aforementioned secondary plots, that for Chabon, the unifying promise of the store was an attractive but unattainable chimera. Reflecting on its closing, he remarks to Archy: "That's what was good about Brokeland. It was all just a theory we had" (617). Chabon appears unable, at the last, to maintain both his realist and utopian narratives. His desire to complicate the possibility 
or authenticity of a nation-state utopia - achieved through the warts-and-all portrayal of American life - weakens the Brokeland narrative in this manner, and leads to its affectionate but final rejection.

As noted, this may appear to acquiesce with DeKoven's thesis. The sense that contemporary utopias must necessarily be 'limited' seems to be supported by the narrative in its final pages, in which Archy, walking away from his closing conversation with Nat, attempts to formulate his priorities after the demise of his business. His thoughts melding with the voice of Chabon, he concludes that "It was all about the neighbourhood, that space where common sorrow could be drowned in common passion as the talk grew ever more scholarly and wild" (624). It is critical, however, to understand exactly what is being rejected in the novel's conclusion. Despite losing its physical location, Brokeland does not entirely close, and if we take into account the fate of Chabon's utopian focal point, then the less sceptical implications of the narrative become clear. The store's reformation into a virtual marketplace indicates an expansion, rather than contraction, of utopian possibility, as Chabon acknowledges the potential of the internet as a means of establishing and accessing communities of shared interest. Operating solely online, the store expands its multicultural customer base beyond the local regulars such as Chan Flowers and Mike Oberstein. Praising his ex-partner's embryonic operation, Archy tells Nat that he will have customers "All over the world. Every time zone, some Samoan, Madagascan motherfucker, hitting you up for a fivethousand-dollar original pressing of Blue Note 1568, deep groove, mono" (616-17). Brokeland is no longer subject to the restrictions of time and place that left it economically unworkable, and its new virtuality allows it to endure as the music-lovers' oasis of Archy's earlier metaphor. At the same moment that its unifying utopianism is emphatically repudiated in a national setting - 'it was all just a theory we had' - the narrative proposes its continuity on a vastly greater scale.

This conclusion, therefore, represents an attempted realignment of utopian thought. The turn away from the nation-state model of utopia does - as DeKoven claims - lead to a reduction in 
Archy's utopian horizons, evinced in his focus on the neighbourhood. Yet, there is an awareness of an original and simultaneous stage on which utopian longing may play out, one made possible by the transformative and unifying effects of new technology. This global stage eclipses that of the state for Chabon, and Brokeland, the locus of the novel's utopianism, is projected onto it, where it once more becomes a community for shared values and interests. There is then a doubled and simultaneous utopianism in the novel's conclusion, expressed in Archy's staunch localism and Brokeland's global magnification. In juxtaposing the two, Chabon distinguishes his utopian vision from that described by DeKoven, offering a rather more optimistic future for the utopian imagination than the academic. It is, I would argue, a future for utopia well-fitted to a globalized and increasingly interconnected world. DeKoven's description of 'limited' utopia does appear suitable in the context of a nation-state beset with contradictions and increasingly superannuated, as depicted by Kumar; with the internet recontextualizing notions of community for large numbers of people worldwide, however, this context seems somewhat lacking.

I do not mean to contend that Chabon articulates a clear path forward under this new paradigm - rather, he offers a single sketch of utopianism turning at once inward and outward from its previous model. Kumar presents a more general formulation in his description of a new direction in non-literary utopian thought: its practitioners "accept the difficulties and dangers of large-scale utopian projects - even if only in the imagination - and promote instead local designs and projects that offer small-scale models of the good life," yet all the while "are acutely aware of the global dimension of their lives, of the need to take into account global forces but also of the opportunities offered by transnational actors and of the resources, intellectual and material, that can be drawn upon from like enterprises elsewhere" $(562,563)$. There is more than something here, I believe, of Chabon's conclusion; the abandonment of unrealistic, unsatisfactory, comprehensive utopian projects, the adoption of smaller, local, projects, and the awareness of and engagement in wideranging global networks. Disillusionment or disappointment in the state, as well as excitement at the 
connective potential of the internet, are central to both. Where Chabon differs is the utopian potential - alongside that resident in the local and the small-scale - that he perceives in global networks. Brokeland becomes such a network, and through Nat's tie-die-wearing, prog-rocklistening, computer-game-playing son Julius, or Julie, Chabon further explores this potential. Unable to fit in with his peers and full of unrequited love for Archy's son Titus, Julie allays the "limitless trances of his loneliness" (141) by taking part in a fantasy role-playing game online. The awkwardness that he feels around Titus disappears online; the two meet online to role-play together so much that Archy, with a tone "somewhere between admiration and disdain," remarks "that's how you friends now. In a game" (623). As an escape from and improvement on the world of his "socalled peers" (125) and hopelessly embarrassing parents, the game offers sought-after reinvention for Julie. In a community shared by countless other players around the world, he plays with a female character, "running ... through the streets of Hammer Bay, on the island of Genosha" (120). Chabon continually emphasizes Julie's felt exclusion from the world around him, and the game presents him with a literal new world. This liberatory function, allowing for the idealization of the self, is presumably shared by the other players online, giving the game-as-network a utopian tenor. As with the new Brokeland Records, the internet enables this network and fosters its community. The narrative then reveals a belief in the possible 'globalization' of utopian thought, made possible by the virtual communities of the internet, and sustained at the same time as a resolutely local utopianism. As an alternative to the enervated nation-state utopianism of the past, it is an attempt to begin thinking about a viable utopianism in the present.

Telegraph Avenue then represents a break from the wholly nostalgic Kavalier and Clay. In the earlier novel, Chabon returns to a period of American self-confidence and certitude, seeing in the nascent world superpower a society receptive to utopian longing. While this period is a clearly generative (and successful) fictional setting for the author, Telegraph Avenue allows Chabon to grapple with and puzzle over the contemporary socio-political issues that evidently concern him. 
The years between its publication and his previous fictional work - The Yiddish Policeman's Union, published in 2007 - saw Chabon write a number of essays articulating support for the Democratic Party and Barack Obama in particular, ${ }^{3}$ indicating a newly public political focus for the author, one which is protracted and developed in Telegraph Avenue. In the context of the novel, however, this focus takes on a different complexion from that of the essays, demonstrating how this latest work represents not only a thematic departure for Chabon, but a more personal political one as well. Consider, for example, one of these essays, published in 2008; writing about the Democratic National Convention, which he attended in order to witness Obama's acceptance of the party nomination, Chabon professes his zealous backing of the politician:

Like a lot of other people, I have been trying to help get Barack Obama elected president of the United States of America for a long time, since shortly before he officially announced his candidacy (a time when, if I stated my belief that Obama could win the Democratic nomination, I was frequently, I don't mind reminding some of you people now, patronized and patted on the head). I can't claim to be fair, or balanced. ("Obama and the Conquest of Denver)

Given this once-ardent and tangible backing, the conclusion of Telegraph Avenue acquires an extra resonance. The viable 'glocal' utopianism of the present that the conclusion espouses clashes with the utopian national rhetoric of the 2004 convention speech, and it seems reasonable to conclude that Chabon's retreat from a national utopian model is - at least in part - due to his own disappointment in Obama's presidency. I do not mean to imply some outright rejection of Obama on Chabon's part, but rather a critical link between the anticlimax of his first term and the eventual contradiction of his speech in Telegraph Avenue.

That the mundane and depressing realities of American political life have affected Chabon's

3 See "The Binding of Isaac" and "Getting Out" in the non-fiction collection Manhood for Amateurs, as well as "Obama and the Conquest of Denver" and "Obama vs. the Phobocracy," articles in The New York Review of Books and The Washington Post respectively. 
outlook on utopia may appear a rather unremarkable point. Millions of people, whether American or otherwise, have felt a sense of deflation or disillusionment at Obama's time in office, with the soaring idealistic rhetoric surrounding his campaign standing in stark contrast to the pragmatic, sometimes indefensible, policies that his government has carried out. While Chabon's disillusionment is more public than most, it shares in a widespread disappointment with the presidency. It is precisely Telegraph Avenue's congruity with this standpoint, however, that I want to emphasize. Although the novel despairs at the obstruction of one utopian dream, it also begins to imagine another, and thereby indicates a possible course for a redirected popular sentiment to take. The hope that so characterized the months before the 2008 election - reflected in and furthered by the iconic red-and-blue portrait of Obama - is not extinguished in Chabon's work, but rather channelled into the forms of community outlined above, the imagining of which demonstrates a viable afterlife for the utopian energy that surrounded the campaign. The overall hopefulness of the novel's conclusion is reinforced by its final image of Archy holding his baby. Having made peace with Gwen and looking toward the future, he pictures himself "one day a few years from now," entering the new business where Brokeland once stood to "see how they put the world together, next time around" (625). Far from being the exclusive concern of the Brokeland community, utopianism is shown to endure in various instances; Archy is assured that there will be a 'next time' in the same location, with the prospects for renewal instantiated in his newborn child. In referring to and redirecting the hopefulness of 2008, Chabon's conclusion then offers a utopian vision that ostensibly responds to a pervasive contemporary desire. It displays the renascent relevance of literary utopia in reflecting and augmenting the wishes of readers, positioning itself as a newly global instance of the form at a time in which its orthodox political representation has been stymied. As such, it attempts to recuperate the genre from the doldrums of Kumar's description and reestablish it as a popular fictional form. 


\section{Works Cited}

Boxall, Peter. Twenty-First-Century Fiction. Cambridge: Cambridge University Press, 2013.

Buell, Lawrence. "The Unkillable Dream of the Great American Novel: Moby-Dick as Test Case.” American Literary History 20.1-2 (2008): 132-155.

Chabon, Michael. "Obama and the Conquest of Denver." The New York Review of Books. 9 October 2008. Web. Accessed March 2014.

---. “Obama vs. the Phobocracy.” Washington Post. 4 February 2008. Web. Accessed March 2014

---. Telegraph Avenue. London: Fourth Estate, 2012.

---. The Amazing Adventures of Kavalier and Clay. New York: Random House, 2000.

DeKoven, Marianne. Utopia Limited: The Sixties and the Emergence of the Postmodern. Durham: Duke University Press, 2004.

Hutcheon, Linda. "Irony, Nostalgia, and the Postmodern." University of Toronto English Library. Web. Accessed March 2014.

Kumar, Krishan. “The Ends of Utopia.” New Literary History 41.3 (2010): 549-569.

Marchese, David. "Michael Chabon's Life in Music.” Spin.com. 21 September 2012. Web. Accessed March 2014.

O'Hehir, Andrew. "Chabon on race, sex, Obama: I never wanted to tell the story of two guys in a record store.” Salon.com. 20 September 2012. Web. Accessed March 2014.

“Transcript: Illinois Senate Candidate Barack Obama.” Washington Post. 27 July 2004. Web. Accessed September 2013. 